\title{
Perlawanan Mahasiswi Bercadar Sebagai Kelompok Bungkam
}

\author{
Alma Syafiera, Suzy S. Azeharie \\ almasyafiera.915160163@stu.untar.ac.id, suzya@fikom.untar.ac.id
}

Fakultas Ilmu Komunikasi Universitas Tarumanagara

\begin{abstract}
Public oftenly stigmatized students who wear the veil. They are afraid of approaching them because the media depicted women with veils as terrorists. Therefore, women with veils categorized can be a mute group. This paper will see how the resistance a women wearing veil who joined the real organization named activities of the muslim student. The goals of this research is to find out how those students with veil as a resistance group against the dominant group in the campus environment. The theory used in the study is a mute group theory. The study uses case study methods with a qualitative descriptive approach to understand phenomenon about the behavior, perception and motivation of a person who is not negotiating. The research data was taken from a semi-structured interview with three key informants through documentation study and literature study. The conclusion of this themselves as well as channeling ideas, developing potential and their lack of confidence in the campus environment. They make their organization as a piece against the defection with open resistance such as following an external work program, campaign and channeling their potential. Closed resistance is done as a discussion between fellow members.
\end{abstract}

Keywords : muted group resistance, students use the veil

\begin{abstract}
Abstrak
Mahasiswi yang menggunakan cadar umumnya mendapatkan stigmatisasi dari lingkungan sekitarnya. Orang-orang takut mendekati mereka karena pengaruh pemberitaan bahwa perempuan bercadar termasuk kategori kelompok radikal. Jumlah mahasiswi bercadar yang sedikit dalam lingkungan kampus dianggap sebagai kelompok bungkam. Penelitian ini akan meneliti bagaimana perlawanan yang dilakukan mahasiswi bercadar yang tergabung dalam organisasi kerohanian di tingkat universitas. Tujuan penelitian ini adalah untuk mengetahui bagaimana perlawanan yang dilakukan mahasiswi bercadar sebagai kelompok bungkam terhadap kelompok dominan di lingkungan kampus. Teori yang digunakan dalam penelitian ini adalah kelompok bungkam. Penelitian ini menggunakan metode studi kasus dengan pendekatan kualitatif deskriptif untuk memahami fenomena tentang apa yang dialami seseorang seperti perilaku, persepsi dan motivasi yang tidak bersifat negosiasi. Data penelitian diperoleh dari wawancara semi terstruktur, pengamatan, studi dokumentasi dan studi kepustakaan. Kesimpulan penelitian ini adalah mahasiswi bercadar memiliki ruang terbatas dalam mengekspresikan diri, menyalurkan ide, mengembangkan potensi dan tidak memiliki kepercayaan diri di lingkungan kampus. Mereka menjadikan organisasi kerohanian yang mereka ikuti di kampus sebagai tempat melawan kebungkaman dengan perlawanan terbuka seperti mengikuti program kerja eksternal, kampanye dan menyalurkan potensi yang mereka miliki. Perlawanan tertutup yang dilakukan seperti berdiskusi antar sesama anggota.
\end{abstract}

Kata Kunci: amahasiswa bercadar, perlawanan kelompok bungkam.

\section{Pendahuluan}

Menjalani kehidupan di lingkungan sosial multikulturalisme penting bagi seseorang untuk menyampaikan pemikiran dan pendapat untuk mengekspresikan diri. Bagi kelompok bungkam kesempatan itu relatif terbatas dan sulit didapatkan. 
Menurut Edwin Ardener, kelompok yang menyusun bagian teratas dari hierarki sosial menentukan sistem komunikasi budaya tersebut. Kelompok dengan kekuasaan yang lebih rendah seperti perempuan, kaum miskin dan orang kulit berwarna harus bekerja dalam sistem komunikasi yang sedang dikembangkan oleh kelompok dominan. Apa yang dikatakan dan dipikirkan kelompok bungkam pertama kali harus bergeser dan perbandingan dengan perkataan kelompok dominan (West dan Turner, 2014). Salah satu kelompok bungkam adalah perempuan bercadar. Perempuan bercadar adalah perempuan muslimah yang menjalankan syariat agama Islam dengan menutup aurat hingga wajah mereka tidak terlihat karena menggunakan cadar. Cadar dipandang sebagai adat Timur Tengah dan bukan suatu bentuk ibadah. Menurut Muhammad Alim Khoiri tidak ada Hadist maupun ayat Al-Quran yang memerintahkan perempuan muslimah untuk menggunakan cadar yang ada hanyalah perintah untuk menutup aurat (Khoiri, 2016).

Walaupun mayoritas penduduk Indonesia beragama Islam, namun perempuan muslimah yang menggunakan cadar masih dipandang negatif atau sering dikaitkan dengan aliran radikalisme di Indonesia. Hal tersebut mungkin disebabkan berita yang muncul di media mengenai perempuan bercadar. Salah satunya mengenai ledakan bom Surabaya tanggal 13 Mei 2018 di GKI Jalan Diponegoro Surabaya, Jawa Timur. Saksi mata melihat bahwa beberapa saat sebelum ledakan bom terdapat sosok perempuan bercadar membawa dua orang anak memasuki area parkir GKI Jalan Diponegoro kemudian bom meledak (https://www.liputan6.com/regional/read/352 3607/sebelumledakan-bom-surabaya-sosok-bercadar-masuki-halaman-gki-diponegoro diakses pada tanggal 7 Oktober 2019 pukul 16.01 WIB).

Alienasi pada perempuan bercadar di Indonesia membuat perempuan bercadar melakukan perlawanan. Salah satu yang dilakukan oleh kelompok perempuan bercadar adalah melakukan aksi "peluk saya" pada 20 Mei 2018 di car free day Bundaran Hotel Indonesia Jakarta Pusat (https://www.liputan6.com/news/read/ 3531841/wanita-bercadar-gelar-aksi-peluk-saya-di-cfd-bundaran-hi diakses pada tanggal 23 September 2019 pukul 19.10 WIB).

Selain aksi agar tidak mendapatkan perlakuan alienasi oleh masyarakat, terdapat beberapa cara yang dilakukan perempuan bercadar. Menurut James C. Scott ada dua bentuk perlawanan yaitu perlawanan publik atau terbuka dan perlawanan tertutup. Perlawanan terbuka dikarakteristikan oleh adanya interaksi terbuka antara kelompok satu dengan kelompok lainnya. Sementara perlawanan tersembunyi ditandai dengan adanya interaksi tertutup dan tidak langsung antar kelompok (Scott, 1981). Sesuai dengan pernyataan tersebut maka organisasi dengan anggota yang memiliki kesamaan tujuan dapat menjadi tempat untuk melawan kebungkaman dari kelompok dominan dengan melakukan perlawanan terbuka yaitu berinteraksi terbuka antara anggota kelompok dan kelompok lain dan perlawanan tertutup yaitu perlawanan secara tidak langsung bersama sesama anggota kelompok. Hal tersebut dilakukan oleh perempuan bercadar yang masih berstatus mahasiswi di salah satu kampus di Provinsi Banten yang tidak memberlakukan larangan penggunaan cadar di lingkungan kampus. Bahkan, mahasiswa bercadar di kampus memiliki organisasi kerohanian agama Islam.

Berdasarkan latar belakang di atas, rumusan masalah penelitian ini adalah "Bagaimana perlawanan yang dilakukan mahasiswi bercadar sebagai kelompok bungkam dalam mengekspresikan dirinya di lingkungan kampus?". Tujuan penelitian yang sedang penulis lakukan adalah mengetahui perlawanan kelompok bungkam oleh mahasiswi bercadar di organisasi keagamaan di kampus. 


\section{Metode Penelitian}

Penulis menggunakan metode penelitian kualitatif secara deskriptif. Metode penelitian kualitatif adalah penelitian yang bertujuan memahami fenomena tentang apa yang dialami oleh subjek penelitian seperti perilaku, persepsi, motivasi tindakan dan sebagainya (Herdiansyah, 2010). Pendekatan kualitatif deskriptif adalah data yang dikumpulkan berupa kata-kata, gambar dan bukan angka. Selain itu semua yang dikumpulkan berkemungkinan menjadi kunci terhadap apa yang sedang diteliti. Laporan penelitian akan berisi kutipan data untuk memberi gambaran penyajian laporan tersebut (Basrowi dan Suwandi, 2008). Pendekatan kualitatif deskriptif tersebut sesuai dengan penelitian ini karena sejalan dengan rumusan masalah yaitu ingin mengetahui perlawanan dari kelompok bungkam mahasiswi bercadar di organisasi keagamaan kampus.

Studi kasus adalah model penelitian kualitatif terperinci mengenai individu atau suatu unit sosial tertentu selama kurun waktu tertentu. Studi kasus adalah suatu model yang bersifat komprehensif, intens, terperinci dan mendalam serta diarahkan sebagai upaya untuk menelaah masalah atau fenomena yang bersifat kontemporer (Herdiansyah, 2010). Berdasarkan penjelasan tersebut studi kasus adalah penelitian mengenai manusia, peristiwa dan latar secara mendalam dalam kelompok maupun organisasi. Peneliti menggunakan metode studi kasus karena ingin melihat mahasiswi bercadar dalam organisasi keagamaan di kampus dalam melawan kebungkaman. Berikutnya, peneliti menyebut dengan organisasi keagamaan di kampus $\mathrm{X}$ yang terletak di Banten. Demi menjaga kerahasiaan, informan dalam penelitian ini ditulis menggunakan inisial.

Metode yang digunakan untuk memperkuat penelitian ini adalah wawancara, observasi, studi dokumentasi dan studi kepustakaan. Dalam penelitian ini penulis melakukan pengolahan dan analisis data dengan melakukan wawancara dan observasi lalu penulis mengolah dan menganalisis data untuk mendapatkan kesimpulan. Menurut Sugiyono, analisis data dalam penelitian kualitatif dilakukan sebelum memasuki lapangan, selama di lapangan dan sesudah di lapangan. Namun analisis data lebih difokuskan pada saat di lapangan. Selain itu analisis data merupakan proses mencari dan menyusun secara sistematis data yang diperoleh dari hasil wawancara, catatan lapangan, bahan-bahan lain sehingga mudah dipahami dan temuan tersebut dapat diinformasikan kepada orang lain. Analisis data dilakukan dengan mengorganisasikan data, menjabarkan data, melakukan sintesa, memilih mana yang penting akan dipelajari dan membuat kesimpulan yang dapat diceritakan kepada orang lain (Sugiyono, 2007). Pengolahan data pada dasarnya tidak bisa dipisahkan dengan proses pengamatan partisipan dan wawancara mendalam di lingkungan subjek (Basrowi dan Suwandi, 2008).

Penulis melakukan triangulasi data pada penelitian ini agar dapat membandingkan data penelitian dan informasi pada penelitian ini bersifat valid. Teknik keabsahan data dapat dilakukan dengan triangulasi pendekatan dengan kemungkinan melakukan terobosan metodologis terhadap masalah tertentu yang kemungkinan dapat dilakukan (Bungin, 2007). Triangulasi adalah teknik keabsahan data dengan memanfaatkan sesuatu yang lain di luar data untuk pengecekan sebagai pembanding terhadap data penelitian. Teknik triangulasi yang paling banyak digunakan adalah pemeriksaan melalui sumber lainnya (Moleong, 2013) 


\section{Hasil Temuan dan Diskusi}

Penulis melakukan wawancara dengan tiga key informan dan tiga informan. Bagi mahasiswi bercadar, pemakaian cadar di lingkungan kampus kerap dianggap menyeramkan dan ditakutkan menganut aliran radikalisme. Perilaku dan pandangan yang mereka dapatkan di lingkungan kampus membuat mereka menjadi kelompok bungkam dan memiliki ruang terbatas dalam mengekspresikan diri, bertukar ide, menunjukkan potensi dan menjalin relasi internal dan eksternal. Hal tersebut membuat mahasiswi bercadar di kampus melakukan perlawanan dengan mengikuti organisasi kerohanian tingkat universitas.

Berdasarkan hasil wawancara dengan Imam Besar Masjid Istiqlal Nasarudin Umar, cadar adalah kain yang menutupi wajah dan merupakan tradisi Timur Tengah. Cadar tidak tercantum dalam Hadist dan ayat Al-Quran sebab kedua pegangan umat Islam ini tidak memerintahkan perempuan muslimah memakai cadar yang ada hanyalah perintah menutup aurat. Namun bagi perempuan muslimah yang menggunakan cadar hal tersebut adalah hak asasi masing-masing individu. Penggunaan cadar di Indonesia maupun di kampus adalah hal yang sah. Namun, ia mengingatkan agar untuk tidak menjadi pengguna cadar yang ideologis. Contohnya mengatakan orang yang tidak menggunakan cadar adalah kafir. Menurut Nasarudin Umar terkadang penggunaan cadar menjadi tempat bersembunyinya kelompokkelompok ideologis garis keras. Hal tersebut tentu mencemarkan nama cadar dan tujuan dari penggunaan bukan lagi untuk pakaian keagamaan namun menjadi pakaian ideologis yang menyudutkan Islam. Penggunaan cadar tersebut bila tetap sejalan dengan Pancasila, Undang-Undang Dasar 1945 dan NKRI maka sah - sah saja. Dalam lingkungan masyarakat penggunaan cadar sering dikaitkan dengan radikalisme. Namun tidak semua pengguna cadar adalah penganut radikalisme atau seorang terorisme. Hal tersebut memang tergantung pada subjektifitas masyarakat mengenai penggunaan cadar dan seharusnya stigma tersebut harus dihilangkan dalam lingkungan masyarakat (berdasarkan hasil wawancara dengan Nasarudin Umar di Masjid Istiqlal, Jakarta Pusat pada tanggal 8 November 2019 pukul 11.00 WIB).

Berdasarkan hasil wawancara dengan informan D yang sudah menggunakan cadar sejak bulan Juli 2019 alasan ia menggunakan cadar adalah karena merasa malu bila tidak menggunakan cadar dan ingin memperbaiki diri. Selain itu ia mempunyai pengalaman sering mendapatkan catcalling dari lingkungannya. Hal tersebut yang membuat dirinya merasa tidak nyaman dan memutuskan untuk menggunakan cadar agar merasa lebih aman terlebih selama berkuliah di kampus. Selain itu keputusan D menggunakan cadar adalah karena terinspirasi dari teman dekatnya yang menggunakan cadar (berdasarkan hasil wawancara dengan D di Banten pada tanggal 1 November 2019 pukul 14.00 WIB).

Salah satu alasan menggunakan cadar berdasarkan hasil wawancara dengan $\mathrm{G}$ adalah ingin menunjukkan kepada banyak orang bahwa perempuan muslimah yang menggunakan cadar tidak selalu menganut aliran radikalisme (berdasarkan hasil wawancara dengan G di Banten pada tanggal 22 November 2019 pukul 16.30 WIB).

Sebagai kelompok bungkam di lingkungan kampus mahasiswi bercadar tidak jarang mendapatkan pandangan miring dan alienasi dari kelompok dominan walaupun mayoritas mahasiswa mahasiswi memakai jilbab dan beragama Islam. Berdasarkan hasil wawancara dengan informan $\mathrm{S}$, setelah menggunakan cadar terdapat banyak perlakuan berbeda yang ia dapatkan. Sebelum menggunakan cadar informan S mengikuti organisasi yang bersifat heterogen. Saat berada di organisasi tersebut 
informan S sering mendapatkan candaan namun secara tidak langsung menyinggung. Informan S menganggap hal tersebut bukanlah suatu candaan. Selain itu setelah menggunakan cadar, teman laki-laki yang dulu akrab dengannya menjadi menjaga jarak dalam berinteraksi. Padahal menurutnya saat berada di lingkungan kampus, teman laki-laki terkadang dibutuhkan dalam pembelajaran maupun tugas kelompok. Saat memakai cadar, informan S merasa tidak dapat menambah teman perempuannya selain di organisasi. Hal lain yang pernah dialami adalah kabar dari adiknya bahwa ketua RT mengunjungi rumahnya di daerah Rangkasbitung dan menanyakan apakah ada yang bercadar di rumah tersebut dan ditakutkan adalah seorang teroris. Beberapa alienasi yang dialami informan $\mathrm{S}$ tersebut ia akui terkadang membuatnya sedih dan menjadi tidak percaya diri. Namun, informan $\mathrm{S}$ berusaha tetap bertahan menggunakan cadar dan mengambil hikmah dari apa yang dialaminya (berdasarkan hasil wawancara dengan informan S di Banten pada tanggal 1 November 2019 pukul 15.30 WIB).

Berdasarkan wawancara dengan informan $\mathrm{G}$, alienasi yang dialami adalah ia menjadi tidak terlalu akrab dengan teman laki-lakinya maupun teman sekelas. Informan $G$ menyadari bahwa hal tersebut berkaitan dengan dirinya yang menggunakan cadar dan dianggap menyeramkan. Namun G merasa dapat mengatasinya karena memiliki teman dekat yang juga bercadar dan tidak membuatnya merasa sendiri. Selain itu setelah menggunakan cadar informan G memang mengurangi interaksi dengan teman sekelasnya karena ingin menjaga citra cadar (berdasarkan hasil wawancara dengan informan $\mathrm{G}$ di Banten pada tanggal 22 November 2019 pukul 16.30 WIB).

Alienasi yang didapatkan mahasiswi bercadar di lingkungan kampus membuat mereka melakukan perlawanan. Salah satu cara melawan kebungkaman mahasiswi bercadar di lingkungan kampus adalah dengan mengikuti organisasi kerohanian agama Islam di tingkat universitas atau organisasi X.

Berdasarkan hasil wawancara dengan informan $G$, tujuannya mengikuti organisasi X sejak menjadi mahasiswi baru tahun 2017 adalah ingin menambah teman seperti keluarga di lingkungan kampus. Gadis memiliki beberapa teman dekat sejak ia mengikuti organisasi X. Setelah mengikuti organisasi keagamaan X, informan G juga merasa tidak sendiri bila ada di lingkungan kampus. Dengan ikut serta dalam program kerja organisasi keagamaan X membuat informan $\mathrm{G}$ lebih percaya diri dan dapat lebih dikenal di lingkungan kampus. Kegiatan yang diikuti antara lain kajian rutin setiap minggu, bimbingan anak, kampanye menutup aurat saat hari Valentine 14 Februari 2019 di lingkungan kampus, berbagai Unit Kegiatan Mahasiswa Kerohanian agama Islam di Provinsi Banten, dan kampanye sedekah di lingkungan kampus (berdasarkan hasil wawancara dengan informan G di Banten tanggal 22 November 2019 pukul 16.30 WIB).

Informan D yang telah mengikuti organisasi keagamaan $\mathrm{X}$ sejak menjadi mahasiswi baru tahun 2018 menyatakan ingin mencoba mengembangkan diri di lingkungan kampus terlebih menurutnya di kelas ia jarang berinteraksi dengan temantemannya karena pendiam. Kegiatan yang diikuti informan D adalah menjadi panitia sekaligus pembaca doa saat selesainya kegiatan dalam program kerja kajian rutin untuk perempuan yang terbuka untuk mahasiswi, bimbingan anak, dan menjadi panitia dalam program organisasi keagamaan tersebut. Informan Dian juga mengikuti lomba membaca Al-Quran dan meraih juara (berdasarkan wawancara dengan informan D di Banten pada tanggal 1 November 2019 pukul 14.00 WIB). 
Berdasarkan hasil observasi penulis, acara kajian rutin eksternal organisasi keagamaan X selalu diadakan setiap hari Jumat dan khusus untuk perempuan. Acara dilakukan di aula kampus dengan pembukaan, sesi sharing dari ustadzah atau orang yang dianggap paham mengenai agama Islam, sesi tanya jawab dan diakhiri dengan pembacaan doa bersama. Pada acara kajian rutin organisasi keagamaan X, informan S aktif bertanya saat sesi tanya jawab dan informan $\mathrm{D}$ menjadi pembaca doa dalam acara tersebut.

Menurut Richard West dan Lynn H. Turner, komunikasi adalah sebuah proses sosial individu menggunakan simbol untuk menciptakan dan menginterpretasikan makna dalam lingkungan mereka (2013). Hubungan teori ini dengan penelitian yang penulis lakukan adalah melalui komunikasi mahasiswi bercadar dapat saling bertukar ide dengan anggota organisasi keagamaan X. Hal tersebut sejalan dengan wawancara informan $\mathrm{G}$ yang mengatakan bahwa mengikuti organisasi keagamaan $\mathrm{X}$ dapat membuatnya mengekspresikan diri, bertukar ide dengan sesama anggota dan menjalin relasi dengan banyak pihak (berdasarkan hasil wawancara dengan informan $\mathrm{G}$ di Banten tanggal 22 November 2019 pukul 16.30 WIB).

Dari pernyataan di atas dapat dirangkum bahwa komunikasi merupakan komponen penting dalam perlawanan kelompok bungkam. Melalui komunikasi dengan anggota organisasi keagamaan $\mathrm{X}$ dan banyak pihak membuat mahasiswi bercadar mampu mengekspresikan diri dan bertukar ide yang terbatas mereka dapatkan di dalam kelas maupun di lingkungan kampus.

Menurut Edwin Ardener, kelompok yang menyusun bagian teratas dari hierarki sosial menentukan sistem komunikasi budaya tersebut. Kelompok dengan kekuasaan yang lebih rendah seperti perempuan, kaum miskin, dan orang kulit berwarna harus bekerja dalam sistem komunikasi yang sedang dikembangkan oleh kelompok dominan (West dan Turner, 2014). Selanjutnya bagi kelompok bungkam apa yang seseorang dalam kelompok bungkam seperti perempuan katakan pertama kali harus bergeser dari pandangan mereka terhadap dunia dan diperbandingkan dengan pengalaman atau perkataan dari kelompok dominan (West dan Turner, 2014).

Hubungan teori kelompok bungkam dengan penelitian ini adalah mahasiswi bercadar merupakan kelompok bungkam. Hal tersebut sejalan dengan hasil wawancara dengan informan D setelah menggunakan cadar hubungannya dengan teman laki-laki di kelas maupun di lingkungan kampus menjadi tidak akrab. Padahal informan D tidak ingin cadarnya tersebut membuat ia dan teman laki-lakinya menjadi berjarak. Informan D juga sering mendapatkan pandangan tidak enak dari teman-teman di fakultas membuat dirinya menjadi lebih diam dan tidak banyak berinteraksi (berdasarkan hasil wawancara dengan informan D di Banten pada tanggal 1 November 2019 pukul 14.00 WIB).

Dari penelitian ini, kelompok bungkam adalah seseorang yang berbeda di dalam lingkungan dan tidak mendominasi. Perkataan dan pemikiran kelompok bungkam harus diperbandingkan dengan kelompok dominan. Mahasiswi bercadar adalah kelompok bungkam. Dalam lingkungan kampus tersebut, mahasiswi yang menggunakan cadar sangat sedikit dan tidak dominan. Adanya pandangan bahwa penggunaan cadar menyeramkan dan ditakutkan menganut aliran radikalisme membuat mahasiswa mahasiswi di kelas dan lingkungan kampus menjaga jarak dengan mahasiswi bercadar.

Mahasiswi bercadar mengalami proses pembungkaman di lingkungan kampus yaitu pelecehan. Menurut Richard West dan Lynn H. Turner terdapat empat proses pembungkaman yaitu mengejek, ritual, kontrol dan pelecehan. Proses pelecehan 
adalah kelompok bungkam dalam lingkungan mereka didominasi oleh kelompok dominan dan tidak memiliki akses untuk menguasai lingkungan tersebut seringkali mendapatkan pelecehan secara verbal seperti terkesan memuji (2014). Hal tersebut sejalan dengan pernyataan informan $\mathrm{S}$ bahwa setelah menggunakan cadar, ia tidak akrab dengan teman laki-laki. Selain itu saat ia menjadi anggota organisasi di tingkat universitas (bukan organisasi keagamaan), informan S pernah mendapatkan candaan dan pujian dari teman-temannya yang menurutnya hal tersebut mengejek. Setelah menggunakan cadar di kelas informan $\mathrm{S}$ merasa interaksi dengan teman-teman kelasnya menjadi tidak terlalu dekat. Hal tersebut membuat $\mathrm{S}$ membatasi diri untuk berinteraksi dan menyampaikan pendapatnya dengan teman laki-laki maupun sekelasnya (berdasarkan hasil wawancara dengan informan $\mathrm{S}$ di Banten pada tanggal 1 November 2019 pukul 16.00 WIB). Penulis merangkum proses pembungkaman adalah perilaku yang membuat diri seseorang merasa terpojok di suatu lingkungan. Seperti proses pelecehan yang dialami S. Maka dalam penelitian ini mahasiswi bercadar mengalami proses pembungkaman di lingkungan kampus.

Penulis menyimpulkan bahwa organisasi keagamaan yang diikuti oleh anggota bercadar dapat menjadi wadah bagi kelompok bungkam yaitu mahasiswi bercadar melakukan perlawanan kebungkaman di lingkungan kampus. Selain itu menurut James C. Scott perlawanan terbagi menjadi perlawanan publik atau terbuka dan perlawanan tertutup. Kedua bagian tersebut dibedakan atas bentuk, karakteristik, wilayah sosial, dan budaya. Perlawanan terbuka dikarakteristikan oleh adanya interaksi terbuka antara kelompok satu dengan kelompok lainnya. Sementara perlawanan tersembunyi ditandai dengan adanya interaksi tertutup dan tidak langsung antar kelompok (Scott, 1981). Sejalan dengan pernyataan tersebut mahasiswi bercadar melakukan perlawanan terbuka di organisasi keagamaan $\mathrm{X}$ dengan mengikuti kampanye, program kerja eksternal dan merasa dapat menjalin relasi, menunjukkan potensi, mengekspresikan diri. Perlawanan tertutup mahasiswi bercadar di organisasi keagamaan $\mathrm{X}$ adalah dapat menyalurkan ide mereka dengan sesama anggota bercadar yang memiliki pemikiran dan tujuan sejalan.

\section{Simpulan}

Pertama, cadar dipandang sebagai bagian dari budaya Timur Tengah. Perempuan yang menggunakan cadar memiliki stigma negatif di Indonesia karena sering dikaitkan dengan aliran radikalisme dan dianggap menyeramkan. Hal tersebut karena pengaruh berita di media mengenai perempuan bercadar. Kedua, mahasiswi bercadar umumnya memiliki kepribadian introvert atau tidak banyak berbaur. Hal tersebut sejalan dengan temuan pada penelitian ini bahwa mahasiswi bercadar hanya memiliki sedikit teman dekat. Ketiga, mahasiswi bercadar di kampus adalah kelompok bungkam. Mereka tidak dapat mengekspresikan diri dengan bebas di lingkungan kampus. Keempat, pembungkaman mahasiswi bercadar karena adanya interaksi sosial seperti tidak akrab dengan teman laki-lakinya setelah menggunakan cadar, dan tidak menambah teman perempuan di kelas. Mahasiswi bercadar menarik diri dan tidak banyak melakukan interaksi sosial. Selain itu mahasiswi bercadar juga mengalami proses pembungkaman seperti pelecehan secara verbal berupa ejekan di kelas maupun lingkungan kampus. Kelima, organisasi keagamaan dengan anggota mahasiswi bercadar menjadi wadah dalam melawan kebungkaman di lingkungan kampus. Keenam, perlawanan mahasiswi bercadar melalui organisasi keagamaan tersebut adalah perlawanan terbuka dan tertutup. 


\section{Ucapan Terima Kasih}

Pada kesempatan ini, penulis mengucapkan terima kasih kepada pihak-pihak yang telah banyak membantu dan memberi dukungan yang sangat luar biasa selama penelitian ini, yaitu para informan penelitian, keluarga dan teman-teman terdekat penulis yang tidak henti memberikan doa, semangat dan dukungan.

\section{Daftar Pustaka}

Azeharie, Suzy (2019) Representasi Perempuan Pelaku Kejahatan Dalam Media Sosial: Analisa Kasus Afriani Susanti. Jurnal SNIT 2012.

Basrowi. Dan Suwandi. (2010). Memahami Penelitian Kualitatif. Jakarta: Jakarta Rineka Cipta.

Bungin, Burhan. (2006). Sosiologi Komunikasi. Jakarta: Prenada Media Group.

Herdiyansyah, Haris. (2010). Metode Penelitian Kualitatif: Untuk Ilmu-Ilmu Sosial. Jakarta: Salemba Humanika.

Khoiri, Alim M. (2016). Fiqih Busana: Telaah Kritis Pemikiran Muhammad Syahrur. Yogyakarta: Kalimedia.

Moleong, Lexy J. (2012). Metodologi Penelitian Kualitatif. Bandung : PT Remaja Rosdakarya.

Scott. James. C. (1981). Domination and The Arts Of Resistance: Hidden Transcripts. New Haven, CT: Yale University Press.

Sugiyono. (2007). Metode Penelitian Kuantitatif Kualitatif dan R\&D. Bandung: Alfabeta.

West, Richard. dan Turner, Lynn H. (2013). Pengantar Teori Komunikasi: Analisis dan Aplikasi. Jakarta: Jakarta Salemba Empat.

https://www.liputan6.com/regional/read/3523607/sebelum-ledakan-bom-surabaya sosok-bercadar-masuki-halaman-gki-diponegoro

https://www.liputan6.com/news/read/ 3531841/wanita-bercadar-gelar-aksi-peluksaya-di-cfd-bundaran-hi 